Original Article

\title{
ANTIBIOTIC USE AT PRIMARY HEALTHCARE CENTERS IN SURABAYA: A SURVEILLANCE STUDY
}

\author{
FAUNA HERAWATI*, IVAN D. HARTONO, DICKY PRANAJAYA, I. PUTU HENDRYX NARINDRA \\ Department of Clinical and Community Pharmacy, Faculty of Pharmacy, University of Surabaya, Road Raya Kalirungkut (60293), East \\ Java, Indonesia \\ Email: fauna@staff.ubaya.ac.id
}

Received: 28 Jan 2017 Revised and Accepted: 19 May 2017

\begin{abstract}
Objective: Antibiotics are considered to be overprescribed in primary health care centers. This study aimed to investigate the defined daily dose (DDD) of antibiotics per 1000 patients visit in a year in primary health care centers, the prevalence of upper respiratory infections (URI) and
\end{abstract} diarrhea, the percentage of antibiotic prescription for URI and diarrhea in Surabaya.

\begin{abstract}
Methods: A surveillance study of antibiotic use was done from the reports and use of drug demand sheet, which called laporan pemakaian dan lembar permintaan obat (LPLPO), outpatient medication card, and health care information and management system of primary health care center, which called sistem informasi manajemen manajemen puskesmas (SIMPUS) in Surabaya. DDD/1000 patients were calculated for describing the antibiotics usage level in each primary health care centers. Three primary health care centers selected based on its antibiotic use or its population density to recognize its antibiotic prescribing percentage for non-pneumonia respiratory tract infection and nonspecific diarrhea.
\end{abstract}

Results: The DDD antibiotic systemic per 1000 patients visit primary health care centers in Surabaya is relatively low. The results found higher prevalence URI does not correlate to the frequent antibiotic prescribed. The prevalence of URI at one primary healthcare center ( $25 \%$ cases) was less than at the other (44\%), but the percentage of antibiotic prescription and the total antibiotic usage were higher (73\%; 1006 DDD/1000 patients vs. 21\%; 675 DDD/1000 patients). The prevalence of diarrhea at primary health care center $2(2,84 \%)$ was less than at primary health care center $1(4,95 \%)$, but the percentage antibiotic prescription and the total antibiotic usage were higher (43\%; $1006 \mathrm{DDD} / 1000$ patients vs 18\%; 675 DDD/1000 patients).

Conclusion: The antibiotic usage at primary healthcare centers in Surabaya was shown to vary widely. Eighty-seven percent (55/63) primary health care centers antibiotic usage was less than 4 DDD/1000 patients day, only two primary health care centers antibiotic usage 6 DDD/1000 patients day, Further research to investigate antibiotic usage and the differences in usage between primary health care centers in treating URI is required.

Keywords: Antibiotic, Primary health care, Defined daily dose (DDD)/1000 patients

(c) 2017 The Authors. Published by Innovare Academic Sciences Pvt Ltd. This is an open access article under the CC BY license (http://creativecommons.org/licenses/by/4.0/] DOI: http://dx.doi.org/10.22159/ijpps.2017v9i7.17324

\section{INTRODUCTION}

Usage of antibiotic in a lot of countries has increased continuously in the last decade especially in primary cares. The antibiotic is overuse, inappropriate use of antibiotic in both quantity and drug choice, i.e. antibiotic prescribed rate in some countries are more than $80 \%$, sometimes contained more than two antibiotics and the percentage of cephalosporin use more than the percentage of penicillins [1]. At primary health care, antibiotic usually indicated for upper respiratory and gastrointestinal infections [1-3] which are often overuse and injudicious. Upper respiratory infection (URI) and diarrhea are an infection which is mostly caused by viral infections and not recommended to be treated with antibiotics without a positive microbial test $[4,5]$. The inappropriate use of antibiotics can lead to antimicrobial resistance. If antibiotics become ineffective, this disease will lead to increase morbidity, healthcare expenditure, and eventually premature mortality [6].

To evaluate the level of antibiotics usage in primary health care, World Health Organization has devised a measurement unit which named defined daily dose (DDD) $[7,8]$. This standard unit can be used to compare drug exposure across health facilities; assigned by WHO and linked to ATC system, readily available, inexpensive, and easy to use [9]. We, therefore, conducted a surveillance study about DDD antibiotic per 1000 patients visit the primary health care centers; the prevalence and the percentage of antibiotics prescription of URI and diarrhea in three primary health care centers in surabaya.

\section{MATERIALS AND METHODS}

The study was conducted in the year 2014. The research object were all 62 primary health care centers in surabaya, particularly three primary health care centers which named bulak banteng (Blk), pegirian $(\mathrm{Pg})$, and gading $(\mathrm{Gd})$ primary health care center. The three primary health care center was chosen based on its antibiotic usage and population density at 2013 . The rate of antibiotic use in the bulak banteng primary health care center is low and in Pegirian is high. Gading primary health care center was located at the most densely populated area. This research has permission from the health department of surabaya. To calculate the percentage of antibiotics prescription in the patient with URI and diarrhea at 2014, data were collected from outpatient medication card which includes patient's name, diagnosis, and treatment received. DDD antibiotic systemic per 1000 patients visit and percentage were calculated. The prevalence of URI and diarrhea cases were obtained from primary health care's information and management system, which called sistem informasi manajemen puskesmas (SIMPUS).

To calculate the DDD/1000 patient days, data were collected from the reports and use of drug demand sheet which include the list of health care's drugs used and the number of drugs used through 2014. DDD/1000 patient days were calculated with the formula below [7-9]:

$\{($ Total antibiotics in a year [gram]/WHO's DDD [gram])/total patient visit in a year $\mathrm{x} 1000$

A searchable version of the complete ATC index with DDDs is available online [8].

\section{RESULTS}

The results found the usage of antibiotic in all 62 primary health care centers in Surabaya varied widely. In 2013 the DDD/1000 patients of 62 primary health care centers were ranged from 247.17 DDD $/ 1000$ patients ( $0.68 \mathrm{DDD} /$ patients day) for Gading primary 
health care until 2175.16 DDD/1000 (5.96 DDD/patients day) patients for Lontar primary health care. Between the five districts of Surabaya, Center Surabaya had the highest DDD/1000 patients with 969.59 DDD/1000 patients (2.7 DDD/1000 patients a day) and East Surabaya was the lowest with 681.09 DDD/1000 patients (1.9 DDD/1000 patients day). Eighty-seventh percent (55/63) primary health care centers antibiotic usage are less than 1500DDD/1000 patients (4 DDD/1000 patient visit per day. In 2014, URI was the disease with the highest number of the case in the all three primary health care centers. URI cases in Blk primary health care were 8072 cases, while in Pegirian (Pg) were 5188 cases and in Gading (Gd) were 525 cases. primary health care with the highest URI prevalence was Bulak Banteng (Blk) with $44.35 \%$ and followed by Pegirian (Pg) with $25.57 \%$ and Gading (Gd) with 2.16\%. The percentage of antibiotic prescription in URI patient was highest in Pg primary health care with $73 \%$, followed by Blk with $21 \%$ and Gd with $12 \%$.

Table 1: The DDD/1000 patients in five districts of surabaya

\begin{tabular}{|c|c|c|c|}
\hline No. & Primary healthcare & DDD/1000 patients & Total patient visit in a year \\
\hline \multicolumn{4}{|c|}{ South surabaya } \\
\hline & Total & 696.65 & 671744 \\
\hline 1. & $\mathrm{Pk}$ & 1615.17 & 3231 \\
\hline 2. & Sd & 1465.90 & 28528 \\
\hline 3. & $\mathrm{Kd}$ & 1299.57 & 53354 \\
\hline 4. & Sw & 1188.47 & 27162 \\
\hline 5. & Pt & 1149.79 & 50368 \\
\hline 6. & Jg & 1072.47 & 50039 \\
\hline 7. & $\mathrm{Dk}$ & 925.24 & 34168 \\
\hline 8. & Wy & 825.15 & 46142 \\
\hline 9. & Wn & 799.06 & 33580 \\
\hline 10. & $\mathrm{Jm}$ & 757.06 & 37438 \\
\hline 11. & Gy & 751.78 & 44557 \\
\hline 12. & $\mathrm{~Kb}$ & 738.85 & 52498 \\
\hline 13. & Swh & 544.52 & 48182 \\
\hline 14. & $\mathrm{Ng}$ & 398.61 & 62236 \\
\hline 15. & $\mathrm{Bn}$ & 390.33 & 38897 \\
\hline 16. & $\mathrm{Gn}$ & 283.09 & 32281 \\
\hline \multicolumn{4}{|c|}{ North surabaya } \\
\hline & Total & 778.46 & 493211 \\
\hline 1. & $\mathrm{Tm}$ & 1560.59 & 12803 \\
\hline 2. & $\mathrm{Pg}$ & 1237.82 & 62279 \\
\hline 3. & $\mathrm{KrS}$ & 1214.61 & 40585 \\
\hline 4. & $\mathrm{Kl}$ & 1125.55 & 27079 \\
\hline 5. & Wns & 1087.95 & 39977 \\
\hline 6. & $\operatorname{Pr}$ & 1065.20 & 53971 \\
\hline 7. & Kn & 1023.59 & 35687 \\
\hline 8. & Sdt & 756.65 & 19392 \\
\hline 9. & Tnh & 728.58 & 54628 \\
\hline 10. & $\mathrm{Mr}$ & 697.47 & 25988 \\
\hline 11. & SdW & 640.28 & 48036 \\
\hline 12. & $\mathrm{Bl}$ & 623.15 & 19513 \\
\hline 13. & $\mathrm{Dp}$ & 482.07 & 53273 \\
\hline No. & Primary healthcare & DDD/1000 patients & Total Patient visit in a year \\
\hline \multicolumn{4}{|c|}{ East surabaya } \\
\hline & Total & 681.10 & 454285 \\
\hline 1. & Tng & 1586.29 & 42367 \\
\hline 2. & Mly & 1300.72 & 32929 \\
\hline 3. & Kpt & 1211.74 & 20109 \\
\hline 4. & Mnr & 1190.35 & 24667 \\
\hline 5. & $\mathrm{Mj}$ & 981.52 & 42670 \\
\hline 6. & $\mathrm{Rn}$ & 922.14 & 35259 \\
\hline 7. & Pc & 877.80 & 40262 \\
\hline 8. & $\mathrm{KlN}$ & 725.95 & 27401 \\
\hline 9. & $\mathrm{Pc}$ & 607.17 & 32813 \\
\hline 10. & Mdk & 517.32 & 31027 \\
\hline 11. & Klr & 333.77 & 48477 \\
\hline 12. & $\mathrm{Gd}$ & 247.17 & 76304 \\
\hline \multicolumn{4}{|c|}{ West surabaya } \\
\hline & Total & 753.13 & 412105 \\
\hline 1. & $\mathrm{Ln}$ & 2175.16 & 20220 \\
\hline 2. & $\mathrm{Bn}$ & 1523.11 & 11181 \\
\hline 3. & Tnj & 1229.03 & 25299 \\
\hline 4. & $\mathrm{Sm}$ & 1185.19 & 54203 \\
\hline 5. & $\mathrm{Smm}$ & 1149.25 & 38733 \\
\hline 6. & As & 1132.58 & 41913 \\
\hline 7. & Blk & 1043.90 & 13024 \\
\hline 8. & $\mathrm{MnK}$ & 988.75 & 63488 \\
\hline 9. & Md & 912.34 & 19012 \\
\hline 10. & Bnw & 875.94 & 28427 \\
\hline 11. & LdK & 692.92 & 31790 \\
\hline
\end{tabular}




\begin{tabular}{|c|c|c|c|}
\hline 12. & $\mathrm{Jr}$ & 615.11 & 25561 \\
\hline 13. & Bls & 510.31 & 39254 \\
\hline \multicolumn{4}{|c|}{ Center surabaya } \\
\hline & Total & 969.60 & 276360 \\
\hline 1. & $\mathrm{Gn}$ & 2155.90 & 19164 \\
\hline 2. & DrS & 1491.09 & 15314 \\
\hline 3. & Kdn & 1315.53 & 45533 \\
\hline 4. & Tbd & 1173.68 & 36917 \\
\hline 5. & Ktb & 1128.46 & 44837 \\
\hline 6. & Pnl & 939.85 & 42677 \\
\hline 7. & Smw & 914.32 & 30199 \\
\hline 8. & Tbr & 768.91 & 41719 \\
\hline $\begin{array}{l}\text { Tot } \\
\text { sur }\end{array}$ & $\begin{array}{l}\text { /1000 patients } \\
2013\end{array}$ & 753.84 & 2307705 \\
\hline
\end{tabular}

Table 2: The comparison of DDD/1000 patients day

\begin{tabular}{lllllll}
\hline Variabel & South & North & East & West & Center \\
\hline $\mathrm{n}$ & 16 & 13 & 12 & 13 & 8 \\
Minimum & 0.8 & 1.3 & 0.7 & 1.4 & 2.1 \\
Maksimum & 4.4 & 4.3 & 4.3 & 6.0 & 5.9 \\
Average & 2.4 & 2.6 & 2.4 & 3.0 & 3.4 \\
Quartile 1 & 1.9 & 1.9 & 1.6 & 2.4 & 2.6 \\
Quartile 2 & 2.2 & 2.8 & 2.5 & 2.9 & 3.2 \\
Quartile 3 & 3.2 & 3.1 & 3.3 & 3.2 & 3.7 \\
\hline
\end{tabular}

Table 3: The comparation of the antibiotic use and URI prevalence

\begin{tabular}{lllll}
\hline Primary healthcare & URI cases & URI prevalence & Percentage of antibiotic prescription & DDD antibiotics/1000 patients visit \\
\hline 1 & 8072 & $44.35 \%$ & $21 \%$ & 675.73 \\
2 & 5188 & $25.57 \%$ & $73 \%$ & 1006.02 \\
3 & 525 & $2.16 \%$ & $12 \%$ & 191.50 \\
\hline
\end{tabular}

Table 4: The comparation of the antibiotic use and the diarrhea prevalence

\begin{tabular}{lllll}
\hline $\begin{array}{l}\text { Primary } \\
\text { healthcare }\end{array}$ & Diarrhea cases & $\begin{array}{l}\text { Diarrhea } \\
\text { prevalence }\end{array}$ & $\begin{array}{l}\text { Percentage of Antibiotic } \\
\text { prescription }\end{array}$ & $\begin{array}{l}\text { DDD antibiotics/1000 patients } \\
\text { visit }\end{array}$ \\
\hline 1 & 1217 & $4.95 \%$ & $18 \%$ & 675.73 \\
2 & 70000 & $2.84 \%$ & $43 \%$ & 1006.02 \\
3 & 108 & $1.13 \%$ & $27.78 \%$ & 191.50 \\
\hline
\end{tabular}

\section{DISCUSSION}

Antibiotic use in primary health care centers in Surabaya, which divided by five districts, is 2.07 DDD/1000 patients visit per day. The uses are relatively low compared with antibiotic consumption in ambulatory care patients in British Columbia 1997-2000 (18 DDD/1000 inhabitant-days) or Armenia 2011 (15.3 DDD/1000 inhabitants per day) $[10,11]$. In the community, the prevalence of respiratory infection and the percentage of visits in which antibiotics were prescribed, are high [12]. In 2014, higher prevalence URI did not correlate to frequent antibiotic prescribed. Blk was the primary health care with the highest number of URI case and prevalence (8072 cases; $44.35 \%$ ), but the percentage of antibiotics prescription (21\%) and the DDD/1000 patients (675.73) was lower than Pg's (73\%; 1006.02). URI is mostly caused by the virus such as adenoviruses, coronaviruses, adenoviruses, enteroviruses, and influenza viruses. The prevalence of URI which caused by bacteria is not more than $10 \%$ and need a throat culture before prescribing an antibiotic [13]. As well as URI, diarrhea should not be treated with an antibiotic but oral rehydration [14]. Therefore those percentage of antibiotic prescription in URI and diarrhea patients reflect an overuse of antibiotic in those all three primary health care centers.

\section{LIMITATION}

The DDD antibiotics calculate based on the reports and use of drug demand sheet, which called Laporan Pemakaian dan Lembar Permintaan Obat (LPLPO) for patients visiting the primary health care center. In a district, patients can have antibiotics not only from the primary health care center but also from the pharmacy between or across the district. Therefore, it is difficult to know antibiotic use by inhabitant in the district.

\section{CONCLUSION}

The antibiotic usage at primary healthcare centers in Surabaya varied widely. The average percentage use of antibiotics for respiratory tract infection non-pneumonia and diarrhea in some primary health care centers in Surabaya is higher than its national indicator, i.e. $20 \%$ and $8 \%$ respectively. Further research to investigate antibiotic indication and the level of URI and diarrhea severity between primary health care centers are required.

\section{CONFLICTS OF INTERESTS}

We wish to confirm that there are no known conflicts of interest associated with the publication and there has been no significant financial support for this work that could have influenced its outcome.

\section{REFERENCES}

1. Teng CL. Antibiotic prescribing for upper respiratory tract infections in the Asia-pacific region: a brief review. Malays Fam Physician 2014;9:18-25.

2. Lam TP, Ho PL, Lam KF, Choi K, Yung R. Use of antibiotics by primary care doctors in Hong Kong. Asia Pac Fam Med 2009;8:1-6.

3. Hermawan, Sari KAK. Pola pemberian antibiotik pada pasien ISPA bagian atas di puskesmas sukasada II pada bulan Mei-Juni 
2014 [skripsi]. Fakultas Kedokteran Universitas Udayana; 2014. Available from: http://ojs.unud.ac.id/index.php/ eum/article/viewFile/11935/8240. [Last accessed on 20 Dec 2016]

4. Public Health England. Management of infection guidance for primary care for consultation and local adaptation. The United Kingdom Department of Health; 2017. Available from: https://www.gov.uk/government/uploads/system/uploads/at tachment_data/file/591916/managing_common_infections.pdf. [Last accessed on 20 Dec 2016]

5. Panduan praktik klinis bagi dokter di fasilitas kesehatan primer. Kementerian Kesehatan Republik Indonesia; 2014. Available from: http://www. kebijakanaidsindonesia. net/id/ unduh/viewdownload/16-peraturan-pusat-national-regulation/ 652-permenkes-ri-no-5-tahun-2014-tentang-panduan-praktikklinis-bagi-dokter-di-fasilitas-kesehatan-primer. [Last accessed on 20 Dec 2016]

6. Antibiotic/antimicrobial resistance. Centers of Disease Control and Prevention; 2017. Available from: https://www.cdc.gov/

7. drugresistance/ [Last accessed on 20 Dec 2016]

8. Guidelines for ATC classification and DDD assignment 2017. WHO Collaborating Centre for Drug Statistics Methodology 2017. Available from: https://www.whocc.no/filearchive/ publications/2017_guidelines_web.pdf. [Last accessed on 20 Dec 2016]

9. ATC/DDD Index 2017. Available from: https://www.whocc.no/ atc_ddd_index/. [Last accessed on 20 Dec 2016]

10. Introduction to drug utilization research. WHO International Working Group for Drug Statistics Methodology, WHO
Collaborating Centre for Drug Statistics Methodology, WHO Collaborating Centre for Drug Utilization Research and Clinical Pharmacological Services; 2003. Available from: http://apps.who.int/medicinedocs/pdf/s4876e/s4876e.pdf. [Last accessed on 20 Dec 2016]

11. Hutchinson JM, Patrick DM, Marra F, Helen Ng, Bowie WR, Heule L, et al. Measurement of antibiotic consumption: a practical guide to the use of the anatomical therapeutic chemical classification and defined daily dose system methodology in Canada. Can J Infect Dis 2004;15:29-35.

12. Versporten A, Bolokhovets G, Ghazaryan L, Abilova V, Pyshnik G, Spasojevic T, et al. Antibiotic use in eastern Europe: a cross-national database study in coordination with the WHO regional office for Europe. Lancet Infect Dis 2014;14:381-7.

13. Shapiro DJ, Hicks LA, Pavia AT, Hersh AL. Antibiotic prescribing for adults in ambulatory care in the USA, 2007-09. J Antimicrob Chemother 2014;69:234-40.

14. Zoorob R, Sidani MA, Fremont RD, Kihlberg C. Antibiotic use in acute upper respiratory tract infections. Am Fam Physician 2012;86:817-22.

15. Brandt KG, de Castro Antunes MM, da Silva GA. Acute diarrhea: evidence-based management. J Pediatr (Rio J) 2015;91:S36-43.

\section{How to cite this article}

- Fauna Herawati, Ivan D Hartono, Dicky Pranajaya, I Putu Hendryx Narindra. Antibiotic use at primary healthcare centers in surabaya: a surveillance study. Int J Pharm Pharm Sci 2017;9(7):41-44. 